\title{
Pengembangan Sistem Deteksi Gas CO pada Gas Hembus Manusia Berbasis Spektroskopi ICOS
}

\author{
Restu Widiatmono ${ }^{1,2}$, Julien Mandon ${ }^{3}$, Frans J. M. Harren ${ }^{3}$, Kusminarto ${ }^{4}$, M. A. Joko Wasono ${ }^{4}$, \\ Mitrayana $^{4}$ \\ ${ }^{1}$ Department of Physics Education, Universitas Negeri Yogyakarta, Yogyakarta, Indonesia \\ ${ }^{2}$ Physics Doctoral Program, Universitas Gadjah Mada, Yogyakarta, Indonesia \\ ${ }^{3}$ Life Science Trace Gas Research Group, Molecular and Laser Physics Department, Radboud University Nijmegen, The \\ Netherlands \\ ${ }^{4}$ Physics Department, Universitas Gadjah Mada, Yogyakarta, Indonesia \\ email: restu@uny.ac.id
}

\begin{abstract}
Abstrak - Pengembangan sistem deteksi gas hembus pernapasan manusia yang memiliki kepekaan tinggi telah dilakukan dalam penelitian ini. Laser QCL (Quantum Cascade Laser) kontinyu dengan panjang gelombang $4610 \mathrm{~nm}$ sebagai sumber radiasi yang dikombinasikan dengan teknik spektroskopi off-axis ICOS (integrated cavity output spectroscopy) digunakan untuk medeteksi gas Karbon Monoksida (CO) bertekanan rendah. Sel sampel gas dengan panjang $15 \mathrm{~cm}$ yang dilengkapi dengan cermin high-finesse sekaligus berfungsi sebagai rongga resonator laser dengan lintasan optik efektif mencapai $400 \mathrm{~m}$. Batas deteksi sebesar 1 ppbv dalam waktu akuisisi kurang dari 2 detik telah berhasil dicapai. Pendeteksian kasar pada gas hembus pernapasan manusia telah berhasil mendeteksi gas CO sebesar 0,7 ppmv.
\end{abstract}

Kata kunci: QCL, ICOS, spektroskopi Serapan, CO, gas hembus manusia

\begin{abstract}
An ultra sensitive exhaled breath gas detection system has been developed. DFB cw quantum cascade laser (QCL) centered at $4610 \mathrm{~nm}$ as a radiation source was used in combination with an off-axis integrated cavity output spectroscopy for carbon monoxide (CO) gas detection in a low gas pressure. a $15 \mathrm{~cm}$ long high-finesse cavity with an effective optical path length of $400 \mathrm{~m}$ has also been used as a sample gas cell. We demonstrated detection limit of 1 ppb with less than 2 second averaging time. 0,7 ppmv concentration of $C O$ has been identified on a robust measurement of an exhaled breath detection.
\end{abstract}

Keywords: $Q C L, I C O S$, absorption Spectroscopy, CO, exhaled breath detection

\section{PENDAHULUAN}

Quantum cascade laser (QCL) telah menempatkan diri sebagai sumber radiasi yang efektif bagi kebutuhan spektroskopi serapan laser/laser absorption spectroscopy (LAS) di rentang tengah inframerah atau panjang gelombang $\sim 3 \mu \mathrm{m}$ sampai $\sim 24 \mu \mathrm{m}$ yang dikenal sebagai daerah umum serapan vibrasi molekular [1]. LAS telah banyak dikembangkan untuk berbagai level deteksi dan sampel gas menggunakan berbagai metode dan teknik [1].

Continuous-wave (CW) distributed feedback (DFB) QCL dengan pendingin thermoelectric (TEC) telah digunakan untuk mendeteksi karbon monoksida (CO) dengan berbagai metode seperti cavity ring down spectroscopy (CRDS) [2], integrated cavity output spectroscopy (ICOS) [3], dan quartz-enhanced photoacoustic spectroscopy (QEPAS) [4]. Banyak teknik juga telah sukses diimplementasikan pada upaya pendeteksian $\mathrm{CO}$ di berbagai kondisi mulai dari pengamatan atmosfir [5], deteksi gas buang pembakaran [6], sampai dengan analisa gas hembus pernapasan manusia [7]. Penelitian terkini melaporkan bahwa teknik ICOS berbasis QCL telah terbukti merupakan metode yang sesuai bagi keperluan pendeteksian gas hembus pernapasan manusia [8].

Pelacakan gas pada gas hembus manusia merupakan tugas yang tidak mudah. Hal ini disebabkan karena selain komponen gas hembus sangat bervariasi level konsentrasinya (dari ppmv, ppbv, sampai pptv), spektra molekul yang ada juga sangat berdekatan dan berpotensi saling mengganggu [7]. Komponen gas (seperti nitric oxide (NO), karbon monoksida (CO), hidrokarbon, hidrokarbon peroksida, dan bahkan karbon disulfida), dalam gas hembus manusia dapat berfungsi sebagai biomarker sebagaimana telah dikompilasi oleh Zhou dkk. [9].

Gas CO dapat digunakan sebagai penanda pada berbagai penyakit misalnya indikasi gangguan hati, oxidative stress, infeksi pernapasan, dan anemia [10]. Kandungan CO pada gas hembus pernapasan orang sehat berkisar antara 1 sampai 5 ppm [11]. Saat ini penelitian mengenai aplikasi analisis gas hembus manusia untuk kepentingan diagnosa biomedis semakin intensif. Analisa gas hembus menggunakan metode serapan laser yang selektif dan berkepekaan tinggi memiliki banyak kelebihan seperti bersifat noninvasive, mudah digunakan, 
mudah diulangi, dapat melakukan pengukuran secara real time (online measurement), meminimalkan gangguan pada pasien, dan memiliki kemampuan mendeteksi perubahan pada tingkat molekuler [12].

Pengembangan sistem yang dilakukan bertujuan untuk menghasilkan detektor gas $\mathrm{CO}$ berkepekaan tinggi yang memiliki kemampuan untuk mendeteksi $\mathrm{CO}$ pada gas hembus manusia secara langsung. Pada makalah ini diperlihatkan sistem detektor gas $\mathrm{CO}$ yang mengkombinasikan teknik ICOS dengan CW-DFB-QCL terbaru berdaya tinggi pada panjang gelombang 4,61 $\mu \mathrm{m}$, dengan sensitivitas pengukuran yang mencapai level sub ppbv.

\section{LANDASAN TEORI}

ICOS atau Off-axis cavity enhanced absorption spectroscopy (CEAS) adalah varian penting dari CRDS yang pertama kali dipublikasikan pada tahun 1998. Pada ICOS, cahaya akan terkopel di dalam rongga resonator dan spektra serapan dapat diperoleh dari kumpulan sinyal cahaya yang ditransmisikan melalui rongga resonator yang memiliki cermin bereflektivitas tinggi (high finesse) [13]. Sebuah rongga resonator high finesse juga berfungsi sebagai filter spektral yang akan menyempitkan lebar garis dari berkas laser yang melewatinya. [14].

Penjajaran berkas cahaya dalam rongga resonator menggunakan pendekatan geometri secara off-axis (OA) dapat secara sistematis menghilangkan terjadinya resonansi antar berkas yang umum terjadi di dalam rongga resonator, tetapi dengan tetap mempertahankan penguatan sinyal serapan yang ada [15]. OA-ICOS secara efektif dapat mengurangi rentang spektral bebas/free spectral range (FSR) dan memberikan peluang untuk dapat melakukan pengukuran yang berkepekaan tinggi $[16,17]$.

Daya laser yang yang melalui rongga resonator dalam pendekatan penjajaran berkas secara off-axis dapat dinyatakan sebagai [17]

$$
I=I_{0} C_{p} \frac{(1-R)^{2}}{2[(1-R)+k L]}
$$

$I_{0}$ adalah daya laser yang datang, $C_{p}$ adalah parameter spatial coupling (dengan tetapan nilai antara 0 dan 1 ), $k$ adalah koefisien serapan, dan $R$ didefinisikan sebagai tetapan reflektivitas cermin. Pada panjang rongga resonator $L$ dan tetapan reflektivitas efektif cermin $R_{\text {eff }}$, maka serapan di dalam rongga resonator kemudian dinyatakan sebagai

$$
A=\frac{k L}{\left(1-R_{e f f}\right)+k L}
$$

\section{EKSPERIMEN}

Skema rangkaian detektor ICOS berbasis QCL diperlihatkan pada gambar 1. Pada sistem ini digunakan sistem laser CW-DFB-QCL type M9501-modified dari
Maxion Inc. berpendingin termoelektrik. Laser ini merupakan laser ragam tunggal dan beroperasi pada panjang gelombang $2169,2 \mathrm{~cm}^{-1}$ atau $4,61 \mu \mathrm{m}$. Daya ratarata laser yang dihasilkan adalah sebesar $\approx 40 \mathrm{~mW}$.

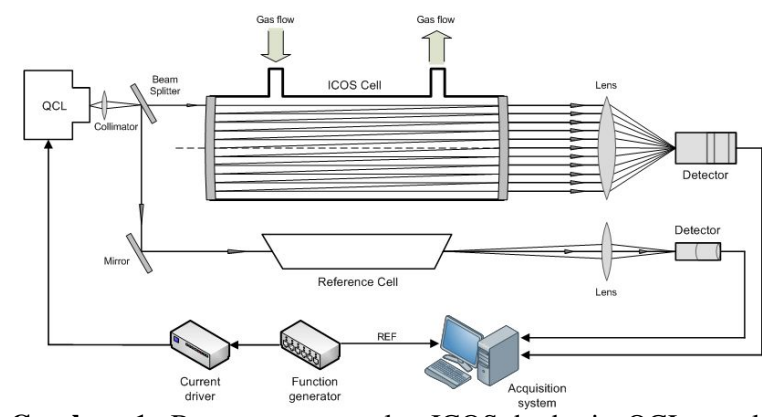

Gambar 1. Bagan susunan alat ICOS berbasis QCL untuk deteksi gas CO pada panjang gelombang $4.61 \mu \mathrm{m}$.

Laser dipasang pada dudukan khusus QCL dengan elemen pendingin Peltier dan dipasang lensa collimator berdiameter $5 \mathrm{~mm}$. Kisaran lebar garis laser berdasarkan spesifikasi Maxion adalah sebesar $3 \mathrm{~cm}^{-1}$. Pemayaran transisi laser pada 4,61 $\mu \mathrm{m}$ dilakukan dengan menetapkan suhu pada $20{ }^{\circ} \mathrm{C}$, dan arus sebesar $418 \mathrm{~mA}$. Pada suhu tetap ini frekuensi keluaran laser disesuaikan dengan melakukan modulasi arus QCL menggunakan sinyal triangular $12 \mathrm{kHz}$. Rentang penyesuaian yang dihasilkan adalah sebesar $0,25 \mathrm{~cm}^{-1}$.

Rongga resonator high finesse $(F \sim 4,500)$ yang digunakan dibuat dari bahan alumunium dengan panjang sebesar $15 \mathrm{~cm}$, dengan volume tabung sebesar $170 \mathrm{ml}$. High finesse diperoleh dengan menempatkan dua buah cermin konkaf berdiameter 1" $(\sim 2.54 \mathrm{~cm})$ buatan CRD Optics Inc. dengan radius kelengkungan sebesar $1 \mathrm{~m}$. tetapan reflektivitas cermin $R$ mencapai $\sim 99.98 \%$ pada panjang gelombang $4,6 \mu \mathrm{m}$. rongga resonator ini juga akan berfungsi sebagai wahana serapan atau wadah sampel gas. Panjang lintasan optik di dalam rongga resonator mencapai $400 \mathrm{~m}$.

Tekanan di dalam sel serapan diatur sebesar 80 mbar menggunakan pompa vakum yang dilengkapi pengatur tekanan secara manual. Aliran gas ke dalam sel diatur sebesar $30 \mathrm{l} / \mathrm{h}$, sehingga hanya membutuhkan waktu sebesar 1 detik untuk menyediakan pergantian gas di dalam sel. Berkas keluaran difokuskan melalui lensa BaF2 $25 \mathrm{~mm}$ (jarak fokus $5 \mathrm{~cm}$ ) pada detektor infra merah. Detektor infra merah yang digunakan adalah detector $\mathrm{HgCd} \mathrm{Te}$ berpendingin thermoelectrik (TEC) empat tahap, dengan preamplifier (PVI-4TE, $D^{*}=$ $\left.4.0 \times 10^{11} \mathrm{cmHz}^{1 / 2} / \mathrm{W}, t=20 \mathrm{~ns}\right)$ buatan Vigo System. Sinyal keluaran dikuatkan penguat $20 \mathrm{~dB}$ (Femto HVA-S, Germany). Data diperoleh dari kartu DAQ (GaGe CompuScope 14200, USA) dan diolah menggunakan program yang dikembangkan menggunakan perangkat lunak LabView.

Sel berisi gas referensi ditempatkan dalam rangkaian alat dan berguna untuk menentukan konsentrasi gas di dalam sel serapan sekaligus untuk memonitor jika 
terterjadi pergeseran panjang gelombang laser. Sel referensi berisi gas $\mathrm{CO}$ dengan konsentrasi $1 \%$ pada tekanan $1 \mathrm{~atm}$. Lensa pemecah berkas dengan konfigurasi $80 \%$ refleksi dan $20 \%$ transmisi digunakan untuk menyediakan berkas laser bagi sel serapan dan sel referensi. Kalibrasi nol atau keadaan tanpa CO dilakukan menggunakan gas $\mathrm{N}_{2}$ yang dialirkan dari tabung khusus yang tersedia.

Pada rentang spectra yang tersedia di dalam QCL yang digunakan terdapat dua garis serapan untuk $\mathrm{CO}_{2}$ dan $\mathrm{CO}$ (berturut-turut sebesar 4.610,6 and $4.610 \mathrm{~nm}$ ). Gambar 2 memperlihatkan simulasi spektra dari campuran $5 \% \mathrm{H}_{2} \mathrm{O}$, $5 \% \mathrm{CO}_{2}, 2$ ppmv $\mathrm{CH}_{4}$, dan 10 ppbv $\mathrm{CO}$ yang mewakili kondisi umum kandungan gas buang pernapasan manusia [18]. Garis-garis spektra yang diperlihatkan pada gambar 2 diperoleh dari simulasi berdasarkan basis data HITRAN 2008 [19].

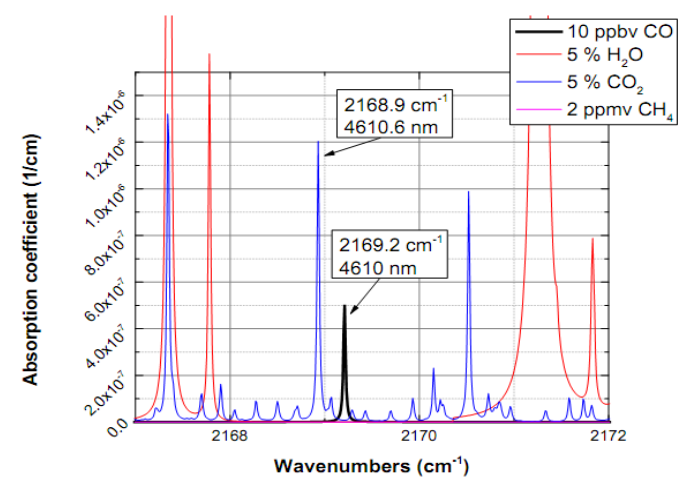

Gambar 2. Simulasi spektra konsentrasi gas pada kondisi umum hembusan pernapasan manusia di daerah panjang gelombang $4,61 \mu \mathrm{m}$.

\section{HASIL DAN PEMBAHASAN}

Pengukuran yang dilakukan bertujuan untuk mengukur performa sistem ICOS berbasis QCL yang dikembangkan dalam mengamati gas $\mathrm{CO}$ pada kondisi umum gas buang pernapasan dengan tingkat kepekaan sub ppb. Kondisi pengukuran yang dilakukan adalah pada konsentrasi gas $\mathrm{CO}$ sebesar 1 ppmv dalam $\mathrm{N}_{2}$. Gambar 3 memperlihatkan tampilan pengukuran yang telah dilakukan.

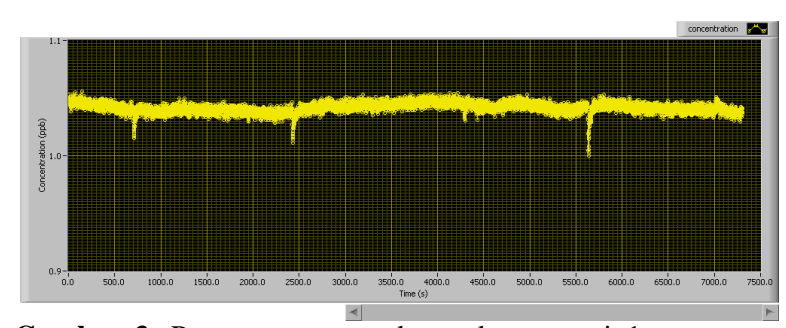

Gambar 3. Pengamatan pengukuran konsentrasi 1 ppmv gas CO selama 2 jam di dalam sel serapan.

Sistem dijalankan selama lebih dari dua jam (sampai 7.300 s) dan pengukuran dilakukan secara bersamaan. Sistem dapat menampilkan pengukuran konsentrasi gas
CO secara visual, sementara pada saat bersamaan data mentah disimpan dalam bentuk file teks. Hasil yang diperoleh memperlihatkan bahwa pengukuran $\mathrm{CO}$ dapat dilakukan secara stabil.

Batas deteksi dari sistem ICOS berbasis QCL, yang akan memberikan gambaran kuantitatif dari kestabilan dan pencapaian kepekaan detektor, diperoleh dengan melakukan analisa data menggunakan standar deviasi dari Allan varriance. Nilai Allan variance dapat menentukan batas deteksi sistem dengan menampilkan besaran derau (noise) sebagai fungsi dari paduan waktu pengukuran [20].

Gambar 4 menampilkan analisa deviasi Allan variance pada pengukuran konsentrasi gas CO sebesar 1 ppmv.

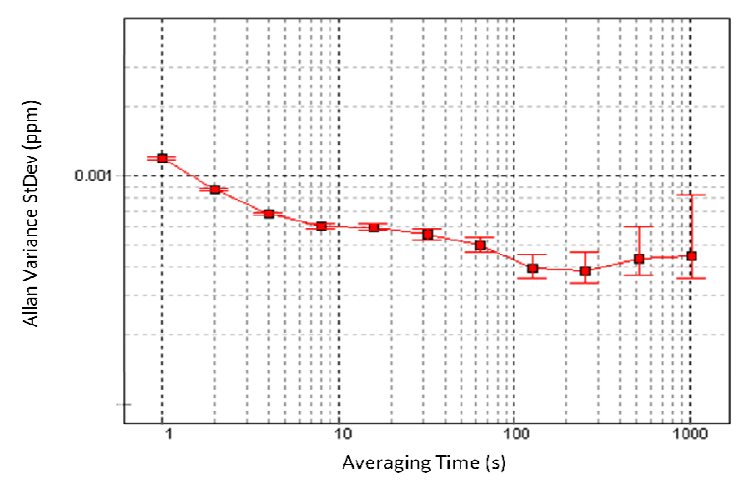

Gambar 4. Analisa Allan variance untuk menentukan batas deteksi pada konsentrasi gas $\mathrm{CO}$ sebesar 1 ppmv.

Batas deteksi dari gambar 4 ditetapkan sebesar 1 ppbv yang diperoleh dalam waktu kurang dari 2 detik waktu akuisisi. Kepekaan yang lebih baik dapat diperoleh dengan melakukan waktu akuisisi yang lebih lama, yaitu 0.4 ppbv untuk waktu akuisisi $115 \mathrm{~s}$.

Gambar 5 memperlihatkan hasil pengukuran kasar dari gas hembus pernapasan manusia.

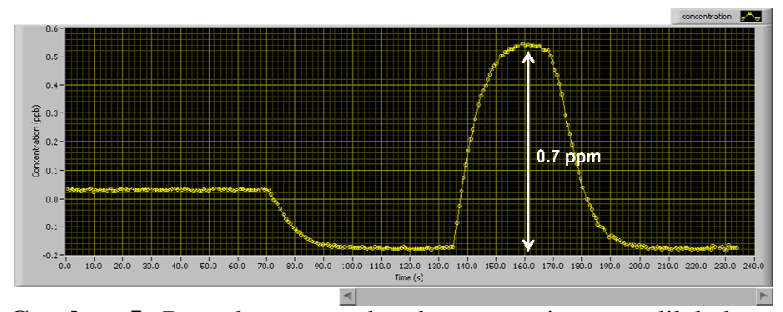

Gambar 5. Pengukuran gas hembus manusia yang dilakukan dapat mendeteksi gas $\mathrm{CO}$ sebesar 0,7 ppmv.

Hasil tersebut menunjukkan bahwa sistem detektor gas CO menggunakan ICOS berbasis QCL ini terbukti mampu melakukan pengukuran dan pengamatan gas $\mathrm{CO}$ dari gas hembus pernapasan dengan tingkat kepekaan yang diinginkan.

\section{KESIMPULAN}

Pengembangan sistem deteksi gas $\mathrm{CO}$ yang menerapkan metode spektroskopi ICOS berbasis QCL 
telah dilakukan dengan baik dengan kepekaan mencapai level sub ppb. Hasil yang diperoleh memperlihatkan bahwa teknik yang digunakan ini dapat dengan cepat dan peka dalam melakukan pelacakan gas $\mathrm{CO}$, walaupun tidak membutuhkan kestabilan posisi rangkaian yang sensitif. Sistem ini terbukti dapat mendeteksi keberadaan gas Co dalam gas hembus pernapasan manusia. Sistem ini memiliki kemungkinan yang cukup baik untuk dikembangkan sebagai detektor gas jenis lain atau diaplikasikan pada penyelidikan biomedik.

\section{PUSTAKA}

[1] A. Kosterev, G. Wysocki, Y. Bakhirkin, S. So, R. Lewicki, M. Fraser, F. Tittel, R.F. Curl, , Application of Quantum Cascade Lasers to Trace Gas Analysis, 2008, Appl. Phys. B 90, 165-176 (2008).

[2] Thomas Fritsch, Peter Hering and Manfred Mürtz, Infrared laser spectroscopy for online recording of exhaled carbon monoxide-a progress report, JOURNAL OF BREATH RESEARCH, 1(2007) 014002 (8pp).

[3] Michelle L. Silva, Richard T. Wainner, David M. Sonnenfroh, David I. Rosen, Mark G. Allen, Terence H. Risby, Mid-infrared Detection of Trace Biogenic Species Using Compact QCL Based Integrated Cavity Output Spectroscopy (ICOS), Proc. SPIE 6010 Infrared to Terahertz Technologies for Health and the Environment, 60100E (November 17, 2005).

[4] Yufei Ma, Rafał Lewicki, Manijeh Razeghi, Frank K. Tittel, QEPAS based ppb-level detection of $\mathrm{CO}$ and $\mathrm{N} 2 \mathrm{O}$ using a high power $C W D F B-Q C L$, OPTICS EXPRESS, Vol. 21, No.1: pp.1008-1019 (14 January 2013).

[5] Lei Tao, Kang Sun, M. Amir Khan, David J. Miller, Mark A. Zondlo, Compact and portable open-path sensor for simultaneous measurements of atmospheric $\mathrm{N}_{2} \mathrm{O}$ and $\mathrm{CO}$ using a quantum cascade laser, OPTICS EXPRESS, Vol. 20, No. 27: pp. 28106-28118 (17 December 2012).

[6] R. Barron-Jimenez, J.A. Caton, T.N. Anderson, R.P. Lucht, T. Walther, S. Roy, M.S. Brown, J.R. Gord, Application of a difference-frequency-mixing based diodelaser sensor for carbon monoxide detection in the 4.44.8um spectral region, Appl. Phys. B 85, 185-197 (2006).

[7] Marcus Sowa, Manfred Mürtz, Peter Hering, Mid-infrared laser spectroscopy for online analysis of exhaled $\mathrm{CO}$, JOURNAL OF BREATH RESEARCH 4(2010) 047101 (6pp).

[8] D. Marchenko, J. Mandon, S. M. Cristescu, P. J. F. M. Merkus, F. J. M. Harren, Quantum cascade laser-based sensor for detection of exhaled and biogenic nitric oxide, Appl. Phys. B (2013) 111:359-365.

[9] Meigui Zhou, Yong Liu, Yixiang Duan, Breath Biomarkers in Diagnosis of Pulmonary Diseases, Clinica Chimica Acta, 413 (2012) 1770-1780.

[10] Chuji Wang and Peeyush Sahay, Breath Analysis Using Laser Spectroscopic Techniques: Breath Biomarkers, Spectral Fingerprints, and Detection Limits, Sensors 2009, 9, 8230-8262.
[11] Matthew R McCurdy, Yury Bakhirkin, Gerard Wysocki, Rafal Lewicki, Frank K Tittel, 2007, Recent Advances of Laser Spectroscopy Based Techniques for Applications in Breath Analysis, JOURNAL OF BREATH RESEARCH, 1(2007) 014001.

[12] J. Wojtas, Z. Bielecki, T. Stacewicz, J. Mikołajczyk, M. Nowakowski, Ultrasensitive laser spectroscopy for breath analysis, OPTOELECTRONICS REVIEW, 20(1):26-39.

[13] Anthony O'Keefe, Integrated cavity output analysis of ultra-weak absorption, Chemical Physics Letters, 293 1998:331-336.

[14] Anthony O'Keefe, James J. Scherer, Joshua B. Paul, $c w$ Integrated cavity output spectroscopy, Chemical Physics Letters, 307, 1999:343-349.

[15] Joshua B. Paul, Larry Lapson, and James G. Anderson, Ultrasensitive absorption spectroscopy with a highfinesse optical cavity and off-axis alignment, APPLIED OPTICS, Vol. 40 No. 27, 20 September 2001:4904-4910.

[16] G. S. Engel, W. S. Drisdell, F. N. Keutsch, E. J. Moeyr, and J. G. Anderson, Ultrasensitive near-infrared integrated cavity output spectroscopy technique for detection of $\mathrm{CO}$ at $1.57 \mu \mathrm{m}$ : new sensitivity limits for absorption measurements in passive optical cavities, Appl. Opt. 45, 9221-9229 (2006).

[17] D. S. Baer, J. B. Paul, M. Gupta, and A. O'Keefe, Sensitive absorption measurements in the near-infrared region using off-axis integrated-cavity-output spectroscopy, Appl. Phys. B 75, 261-265 (2002).

[18] Jagadeeshwari Manne, Alan Lim, Wolfgang Jäger, John Tulip, Off-axis cavity enhanced spectroscopy based on a pulsed quantum cascade laser for sensitive detection of ammonia and ethylene, APPLIED OPTICS, Vol. 49, No. 28, 1 October 2010.

[19] L.S. Rothman, I.E. Gordon, A. Barbe, D. Chris Benner, P.F. Bernath, M. Birk, V. Boudon, L.R. Brown, A. Campargue, J.P. Champion, K. Chance, L.H. Coudert, V. Dana, V.M. Devi, S. Fally, J.M. Flaud, R.R. Gamache, A. Goldman, D. Jacquemart, I. Kleiner, N. Lacome, W.J. Lafferty, J.Y. Mandin, S.T. Massie, S.N. Mikhailenko, C.E. Miller, N. Moazzen Ahmadi, O.V. Naumenko, A.V. Nikitin, J. Orphal, V.I. Perevalov, A. Perrin, A. Predoi Cross, C.P. Rinsland, M. Rotger, M. Šimečková, M.A.H. Smith, K. Sung, S.A. Tashkun, J. Tennyson, R.A. Toth, A.C. Vandaele, J. Vander Auwera, The HITRAN 2008 molecular spectroscopic database, Journal of Quantitative Spectroscopy \& Radiative Transfer, Vol. 110 (2009) 533572, doi:10.1016/j.jqsrt.2009.02.013.

[20] P. Werle, R. Mücke, F. Slemr ,The Limits of Signal Averaging in Atmospheric Trace-Gas Monitoring by Tunable Diode-Laser Absorption Spectroscopy (TDLAS), Applied Physics B, August 1993, Volume 57, issue 2, pp 131-139. 